\title{
METODA BACKPROPAGATION PADA JARINGAN SYARAF TIRUAN DIGUNAKAN UNTUK PENILAIAN KEMAMPUAN BERTAHAN PADA BAYI DENGAN BERAT LAHIR RENDAH
}

\author{
Akik Hidayat $^{1)}$, Juli Rejito ${ }^{2)}$, Sandy P. Kusuma ${ }^{3)}$ \\ Email: ${ }^{1)}$ akik.hidayat@ymail.com, ${ }^{2)}$ irejito@gmail.com, ${ }^{3)}$ sandyfirman@yahoo.com
}

Program Studi Teknik Informatika, Departemen Ilmu Komputer, FMIPA Universitas Padjadjaran

\begin{abstract}
Babies which born with low weight will get so many problems because they're not ready yet to life out of pregnancy. Those make the number of pain and mortality of baby increase. Data mining can be used for predicting the assessment of low weight baby ability to survive earlier. Back propagation artificial neural as a techniques from data mining can be used to analyze data in order to predict the survival ability of low weight babies. In this paper, was built a system based on Back propagation artificial neural to assess whether high or low of the survival low weight babies. From the system which has been made, shows that it has high accuracy level to assist survival ability of low weight babies for $83,33 \%$.

Keywords - low birth weight babies, data mining, artificial neural networks

\section{ABSTRAK}

Bayi berat lahir rendah akan mengalami banyak masalah karena belum siapnya hidup diluar kandungan. Hal tersebut menyebabkan angka kesakitan dan angka kematian pada bayi meningkat. Data mining dapat digunakan untuk mengetahui penilaian kemampuan bertahan lebih dini pada bayi berat lahir rendah. Jaringan syaraf tiruan backpropagation sebagai teknik dari data mining dapat digunakan untuk menganalisis data sehingga dapat memprediksi kemampuan bertahan pada bayi berat lahir rendah. Pada paper ini dibangun suatu sistem berbasis jaringan syaraf tiruan backpropagation untuk menilai tinggi atau rendahnya kemampuan bertahan pada bayi berat lahir rendah. Dari sistem yang dibuat memiliki tingkat keakuratan untuk menilai kemampuan bertahan bayi berat lahir rendah sebesar $83,33 \%$.

Kata kunci — Bayi berat lahir rendah, Data mining, Jaringan syaraf tiruan
\end{abstract}

